\title{
Dose-dependent Attenuating Effects of Aqueous Extract of Carica papaya Seed on CarbonTetrachloride-Induced Renal Toxicity in Rats
}

\author{
Eze Kings le y Nwangwa \\ Department of Phy siology, Faculty of Basic Medical Sciences, College of Health Sciences, Delta State University, P.M.B. 001, \\ Abraka.Delta State. Nigeria
}

\begin{abstract}
A reasonable population of the world today uses herbal drugs.Carica papaya is one of those fruits that is documented to have the potentials of being used for medicinal purposes.In the present study, theeffects of aqueous extract of Carica papaya seeds on a CCl4-induced renal toxicity was studied. A total of thirty (30) Wistar rats were randomly divided into five groups $(\mathrm{n}=6)$. Group 1 (control)was administered with rat chow and water. Group 2,3,4 and 5 received CCl4intraperitoneally (IP) at a dose of $0.8 \mathrm{mg} / \mathrm{kg}$ and group 3, 4 and 5 received in addition $100 \mathrm{mg} / \mathrm{kg}, 200 \mathrm{mg} / \mathrm{kg}$ and $300 \mathrm{mg} / \mathrm{kg}$ extract of Carica papayafor 28 days orally respectively. Samples were collected and assayed for the renal function markers (urea, creatinine and electrolyte). Results obtained showed a dose-dependent statistically-significant decrease in therenal function markers except potassium, which suggests that the extract has a nephro-protective effect. These findings need be further investigated for application in the health care delivery.
\end{abstract}

Keywords Carbontetrachloride, Nephro-Toxicity, Carica Papaya, Renal Function Markers, Free Radical Scavengers

\section{Introduction}

In the long history of the world, plants have been used medically. A large and increasing number of patients use medicinal herbs or seek the advice of their physician regarding their use[1]. It has been estimated roughly, that presently more than half of the total population of the world use herbal drugs[2]. Attention has been given to some tropical fruits that are of economic importance[3] amongwh ich Carica papaya (pawpaw) is one.

The Carica papaya (CP) is a member of the s mall family Caricaceae commonly grown in West Indies, Philippines, $\mathrm{Sr}$ i Lanka, India, Bangladesh, Malaysia and othercountries in tropical America. There are a lot ofcommercial products prepared from different parts of Carica papayaplant such as fruit juice, seed oil and supplement forhealth. The different parts of the plant (the fruits, leaves, latex and seeds) can be eaten and also havebeen used for medicinal purposes as claimed traditionallyfor treatment of different ailments[4] andwound healing[5].

Some of thetraditional claims have been investigated Scientifically using animal model and the efficacy has been proven[6,7]. Recent studiesshowed that Carica papayaleaf

\footnotetext{
* Corresponding author:

drezekingx@yahoo.com (Eze Kingsley Nwangwa)

Published online at http://journal.sapub.org/als

Copyright (C) 2012 Scientific \& Academic Publishing. All Rights Reserved
}

extract has been found to havepotential anti sickling (inhibition of sickle cell formation)[7]and has protective effect againstgastric ulcer in rats[6]. The flowers areknown to have antibacterial activities [8]. Oral administration of the seed extract could inducereversible male infertility and could be used forpharmaceutical development of a male contraceptive[9].

Literature on the effect of Carica papaya leaf extract on the kidney function and histology is scanty[10] and studies on the direct effect of aqueous extract of Carica papaya seedon the organis scarce.

Carbon tetrachloride $\left(\mathrm{CCl}_{4}\right)$ is a well known toxicant to both the liver and kidneys. It is said to induce an acute kidney damage by the formation of free radicals that causes oxidative stress.[11].

Therefore, the presentstudy is to investigate the effect of aqueous extract of Carica papaya seeds on the kidney function markers in $\mathrm{CCl}_{4}$ induced renal toxicity inadult $\mathrm{W}$ istar rats.

\section{Materials and Methods}

\subsection{Plant Authentication and Extract Preparation}

Carica papaya fruit was bought from a local market in Abraka, and was authenticated at the Botany Department, Delta State University, Abraka. The fruit was peeled and the seeds were collected, air dried and later grounded. Then 
they were weighed, $170 \mathrm{~g}$ of the grounded seed were soaked with $2000 \mathrm{ml}$ of distilled water for 72 hours and the residue was separated from the solvent. The solvent was concentrated to a paste like solid with a heating mantle yielding $36 \mathrm{~g}$. The extract was kept in a clean container and refrigerated until use.

Thirty male Wistar alb ino rats $(200-305 \mathrm{~g})$ obtained from the Animal house of the Faculty of Basic Medical Sciences, University of Benin, Benin City, were used for the study. They were kept in rat cages in a well-ventilated house, at the Animal House of the Faculty of Basic Medical Sciences, Delta State University. They were exposed to 12 hours light and 12 hours darkness and fed with clean tap water and rat chow once daily $(8.00 \mathrm{am}-9.00 \mathrm{am})$. They were allowed to acclimatize for fourteen (14) days prior to the experiment.

\subsection{Che mic al and Reagent}

Carbon tetrachloride, reagents and kits for analysis of kidney function markers were obtained from Sig ma (USA) and they were of good analytical grade.

\subsection{Extract Administration}

The admin istration of the extract was done orally with the help of an orogastriccanulla once daily between the hours of 0900a m and 1000a m for a period of 28 days.

\section{5. $\mathrm{CCl}_{4}$ Induced Acute Kidney Damage}

To induce renal toxicity $\mathrm{CCl}_{4}$ was administered intra peritoneally (IP) at a dose of $0.8 \mathrm{mg} / \mathrm{kg}$ as a $30 \%$ solution daily for 28 days..

\subsection{Experimental Design}

A total of thirty (30) W istar albino rats were randomly divided into five groups of six rats each.

Group A:(Control) fed with rat chow and water ad libitum

Group B:fed with rat chow, water ad libitum and received $0.8 \mathrm{mg} / \mathrm{kg} \mathrm{CCl} 4$

Group C:fed with rat chow, water daily, $0.8 \mathrm{mg} / \mathrm{kg}$ $\mathrm{CCl}_{4}$ and then received dose of $100 \mathrm{mg} / \mathrm{kg}$ of aqueous ext ract of C. papaya seeds.

Group D: fedwith rat chow, water daily, $0.8 \mathrm{mg} / \mathrm{kg}$ $\mathrm{CCl}_{4}$ and then received dose of $200 \mathrm{mg} / \mathrm{kg}$ of aqueous extract of C. papaya seeds.

\subsection{Animal Handling}

Group E: fed with rat chow, water daily, $0.8 \mathrm{mg} / \mathrm{kg} \mathrm{CCl} \mathrm{Cl}_{4}$ and then received a dose of $300 \mathrm{mg} / \mathrm{kg}$ of aqueous extract of C. papaya seeds.

\subsection{Collection of Samples}

The rats were sacrificed by decapitation after an overnight fast. Blood samples were collected from the heart by cardiac puncture and put in a plane sample bottle and the serum was stored until used for analyses.

\subsection{Serum Biochemical Assay}

In the assessment of serum urea, creatinine, and electroly tes blood samples were obtained directly from theheart chamber of the ratsand were kept at the temperature of $4{ }^{\circ} \mathrm{C}$ for 2 hours before they were centrifuged usingLaboratory Centrifuge (ModelSM 902B, Surgifriend Medicals, England,U.K.). The urea and creatinine levels in all the serum sample were estimated by modified methods based on diacetyl monoximereaction[12] and Jaffe'sreaction[13], resp ectively, on standard diagnostic test kits (Randox Laboratories, Crumlin, U.K.)on Automated Clinical System (SychronClinical System ${ }^{\circledR}$, model: CX5 PRO)(Beckman Coulter Inc., Galway, Ireland). The absorbance of samples was measured spectrophotometrically at $580 \mathrm{~nm}$ against a reagent blank.

\subsection{Ethical Consider ations}

Permission was granted by the Ethical Committee of the Delta State University, to carry out this study for the required period of time and the provisions of the declaration of Helsinki 1995 were co mp lied with.

\subsection{Statistical Analysis}

Results were expressed as mean \pm SD. The evaluation of data for statistical significance between control and experimental groups was done using one way ANOVA. The Turkey multiple comparison test was used to determine specific pairs of organs that were statistically different. Statistical software, SPSS 17, was used to analyze the data. A $P<0.05$ was accepted as statistically significant.

\section{Results}

Table 1. Effect of Carica papaya seed aqueous extract on the kidney funct ion parameters and electrolytes of Wistar rats

\begin{tabular}{|c|c|c|c|c|c|}
\hline Enzymes & Group A (Control) & Group B CCl4 & $\begin{array}{c}\text { Group C Cl4+ } \\
100 \mathrm{mg} / \mathrm{kg}\end{array}$ & $\begin{array}{c}\text { Group DCCl4 } \\
+200 \mathrm{mg} / \mathrm{kg}\end{array}$ & $\begin{array}{c}\text { Group ECCl4+ } \\
300 \mathrm{mg} / \mathrm{dl}\end{array}$ \\
\hline $\mathrm{Na}+(\mathrm{mg} / \mathrm{dl})$ & $140.00 \pm 8.08$ & $208.20 \pm 0.23^{*}$ & $133.00 \pm 12.7+$ & $117.50 \pm 4.04^{*}+$ & $107.00 \pm 8.08+$ \\
\hline $\mathrm{K}+(\mathrm{mg} / \mathrm{dl})$ & $5.35 \pm 0.06$ & $3.25 \pm 0.02^{*}$ & $4.65 \pm 0.29$ & $5.10 \pm 0.23+$ & $5.15 \pm 0.06+$ \\
\hline $\mathrm{Cl}-(\mathrm{mg} / \mathrm{dl})$ & $96.00 \pm 4.62$ & $122.08 \pm 072 *$ & $88.50 \pm 4.04+$ & $80.20 \pm 4.04^{*}+$ & $72.50 \pm 4.04 *+$ \\
\hline Ure a (mg/dl) & $34.20 \pm 6.35$ & $88.52 \pm 0.15^{*}$ & $37.50 \pm 12.47+$ & $45.45 \pm 1.21^{*+}$ & $47.55 \pm 5.25^{*}+$ \\
\hline $\begin{array}{c}\text { Creatinine } \\
(\mathrm{mg} / \mathrm{dl})\end{array}$ & $1.05 \pm 0.06$ & $10.22 \pm 0.45^{*}$ & $1.13 \pm 0.06+$ & $1.15 \pm 0.06^{*+}$ & $1.25 \pm 0.06 *+$ \\
\hline
\end{tabular}


In this study, changes in the levels of kidney function markers and electrolytes due to the effect of different doses of the Carica papayaseed aqueous extract on rats were compared to those of the control. The treated rats were administered with different doses of the extract after receiving $\mathrm{CCl}_{4}$ to xicant.

Values are presented as means $\pm \mathrm{SD} ; P<0.05$ co mpared with control group, $P<0.05$ compared with group $\mathrm{B}(\mathrm{n}=6)$

The table above shows that administration of Carica papayacaused a dose-dependent and statistically significant decrease in the values of the kidney function markers and electrolytesinWistar rats,especially the dose of $200 \mathrm{mg} / \mathrm{kg}$ and above. The aqueous extract of the plant seed caused a significant decrease $(P<0.05)$ in the $\mathrm{Na}^{+}$,and $\mathrm{Cl}^{-}$levels, and a non significant increase in $\mathrm{K}+$ level, it also showed a significant reduction $(P<0.05)$ in the urea and creatinine compared with $\mathrm{CCl}_{4}$ only treatment group (Group B)

\section{Discussion}

The use of $\mathrm{CCl}_{4}$ to induce renal toxicity is well documen ted. $\mathrm{CCl}_{4}$ has been shown to have hepatotoxic and nephroto xic potential[14].

Serum urea, creatinine and electrolytes are reliable and effective markers of renal function which could be indicative of the extent of the renal damage[15].

In this present study therefore, the use of the extract of Carica papaya seeds to modulate the effect of this nephroto xic substance is investigated. The findings confirmed the nephrotoxic potentials of $\mathrm{CCl}_{4}$ as shown by the statistical significant $(P<0.05)$ increase in all the parameters of renal function markers (Group B) except for potassium which showed a significant decreased level compared with the control (Group A).

Furthermore, th is study showed a dose-dependent statisti cally significant $(P<0.05)$ decrease in the renal function markers (urea, creatinine and electrolytes) in the groups administered with $100 \mathrm{mg} / \mathrm{kg}, 200 \mathrm{mg} / \mathrm{kg}$ and $300 \mathrm{mg} / \mathrm{kg}$ of the extract of Carica papaya seeds compared with theCCl${ }_{4}$ only administered group (Group B) except for potassiun that showed a non-significant increase compared with the $\mathrm{CCl}_{4}$ only treated group.

Production of free Oxygen radical is one of the theories that explain the mechanism of cell injuries and damage and the presence of antioxidants have been found to be very useful in modulating the destruction. The phytochemical analysis of Carica papaya seeds extract is documented to contain alkaloids,saponin, vitamin $\mathrm{B}_{12}$, vitamin $\mathrm{C}$, antioxid ants, anthraquinonesetc[16].

Since $\mathrm{CCl}_{4}$ produces its acute renal damage by causing oxidative stress through release of destructive free radicals, it is possible that the protective effect of Caricapapayaobse rved in this study may be a result of its antioxidant effect and/or free radicals scavenging effect which helps to detoxify the free radicals and reduce the lipid peroxidation arising from injury to cell membrane.

\section{Conclusions}

This study suggests that aqueous extract of Carica papay $a$ seeds may have a nephroprotective effect on acute kidney damage especially if the mechanism of damage is by inducing oxidative stress. Therefore these findings need be further investigated for possible use in health care delivery.

\section{ACKNOWLEDGEMENTS}

The researcher wish to thank Augustine Godswill and EkhoyeEhitare for their contribution in this research work and the technical staff of the Department of Chemical Pathology, University of Benin Teaching Hospital, Benin Nigeria.

\section{REFERENCES}

[1] O’Hara M, Kiefer D, Farrel K, Kemper K (1998): A review of 12 commonly used medicinal herbs. Archives of Family Medicine. 7: 523 - 536 .

[2] Chang, I.M. (1987): Toxicity of herbal drugs. International Forum on Research and Development for procedures involving Risk assessment of Toxic chemicals. In Korean Soc. Toxicol. $243-257$.

[3] Glombitza, K.W., G.H. Mahran, Y.W. Mirhon, K.G. Michael and T.K. Motawi, 1993. Hypoglycemic and AntihyperglycemicEffects of ZizyplusSpinachristi inRats. Planta. Med., pp: 244-247.

[4] Wiart C (2002). Medicinal Plants of Southern Asia. Prentice HallPearson Malaysia Sdn. Bhd.

[5] Nor Suhada A, ShafiyyahSolehah Z, Ibrahim Adham T, MohammadTariqur R (2008). Effect of green and ripe Carica papayaepicarpextracts on wound healing and during pregnancy. Food Chem.Toxicol., 46 (7): 2384-2389.

[6] Indran M, Mahmood AA, Kuppusamy UR (2008). Protective effect ofCarica papaya L leaf extract against alcohol induced acute gastricdamage and blood oxidative stress in rats. West Indian Med. J.,57(4): 323.

[7] Imaga NOA, Gbenle GO, Okochi VI, Akanbi SO, EdeoghonSO,Oigbochie V, Kehinde MO, Bamiro SB (2009). Antisickling property ofCarica papaya leaf extract. Afr. J. Biochem. Res., 3(4): 102-106.

[8] Zakaria ZA, Jais AM, Sulaiman MR, Mohamed Isa SSP, Riffin S (2006).The in vitro Antibacterial of Methanol and Ethanol Extracts of Caricapapaya Flowers and Mangiferaindica Leaves. Pharmacol. Toxicol.,1(3): 278-283

[9] Udoh FV, Udoh PB, Umoh EE (2005). Activity of Alkaloid Extract ofCarica papaya Seeds on Reproductive Functions in male WistarRats. Pharmaceut. Biol., 43(6): 563-567.

[10] Olagunjua, JA Adeneyeb, AA Fagbohunkac, BS Bisugac, NA Ketikuc, AO Benebod,AS Olufowobic, OM Adeoyec, AG Alimic, MA Adelekec, AG. (2009): Nephroprotective 
activities of the aqueous seed extract ofCarica papaya Linn. in carbon tetrachloride induced renal injured Wistar rats: a dose- and time-dependent study. Biology and Medicine, Vol. 1 (1): 11-19.

[11] Recknagel, R.O., Glende Jnr, E.A and Britton, R.S, 1991. Free Radical Damage and Lipid peroxidation In:Meeks, R.G., (Ed.), Hepatotoxicity. CRC Press, Florida, pp:401-436.

[12] Marsh WH, Fingerhut B, Miller H, (1965).Automated and manual direct methods for thedetermination of blood urea. Clinical Chemistry,11(6): 624 - 627.

[13] Biod T, Sirota B, (1948). In: Watson, A., et al.(Eds.). Practical Clinical Biochemistry.Prentice-Hall of India Private Ltd., New Delhi,India. pp. 142 - 145.
[14] Ganie, S.H., Haq, E.,Hamid, A.,Qurishi, Y.,Mahmood, Z and Zargar,B.A, 2011. Carbon tetrachloride induced kidney and lung tissue damages and antioxidant activities of the aqueous rhizomes extract of podophyllum hexandrum, BMC Complem. Alt. Med., 11:17-23.

[15] Adelman, R.D., Spangler, W.L., Beasom, F., Ishizaki, G and Conzelman, G.M, 1981. Frusimide enhancement ofnelticimin nephrotoxicity in dogs. J.Antimicrob.Chemothe r., 7:431-440.

[16] Marfo, E.K., Oke, O.C., Afolabi, O.A 1986. Chemical composition of Papaya (Carica papaya) seeds. Food Chemistry 22(4) 259-266. 